\title{
Juvenile crime drop: What is happening with youth in Spain and why?
}

European Journal of Criminology

$1-26$

(C) The Author(s) 2018

Article reuse guidelines: sagepub.com/journals-permissions DOI: I0.1 I77/I4773708|8792383 journals.sagepub.com/home/euc

@SAGE

\author{
Esther Fernández-Molina $(i)$ and \\ Raquel Bartolomé Gutiérrez iD \\ University of Castilla-La Mancha, Spain
}

\begin{abstract}
One of the most robust findings in criminology is the fall in crime rates throughout the Western world. However, there is still much to be learnt about this and its causes. This case study analyses the Spanish juvenile crime trends and tests the explanatory capacity of the sociodemographic hypotheses. We use aggregate data provided by the police and self-report data. Our analysis could be of interest in a worldwide debate on the crime drop. Demographic changes and the economic situation have little relevance in explaining the changes. However, public policies seem to have had a greater impact on crime trends. Furthermore, gender equality can be considered a possible explanatory factor.
\end{abstract}

\section{Keywords}

Crime drop, crime trends, juvenile delinquency, self-reported juvenile delinquency

\section{The crime drop}

One of the clearest scientific trends in the world of criminology is that crime is declining throughout the Western world, especially homicide and property crime. Hence, this 'crime drop' has become one of the most important criminological phenomena of modern times (Farrell et al., 2014).

The United States was the first country to detect this drop. After a progressive increase in crime rates, especially violent crime, starting in 1950, a decline was first noted in the 1990s and, over time, this trend was confirmed. Against all the odds, all types of crime

\section{Corresponding author:}

Esther Fernández-Molina, Associate Professor, Research Group in Criminology and Juvenile Delinquency, University of Castilla-La Mancha, Benjamín Palencia Building, Campus Universitario s/n, Albacete, 0207I, Spain. Email: esther.fdez@uclm.es 
began to decrease substantially, thus reversing what had been an upward forecast. Some criminologists such as Blumstein and Wallman (2006) or Zimring (2006) described and tried to explain this decline and sparked a debate in an attempt to come up with alternative explanations. An ageing population, stronger economies, increased gun control, the rise in incarceration rates, bigger police forces, better preventive policing, the overall drop in crack cocaine use, and some more provocative explanations such as the legalization of abortion or less lead poisoning, were the main hypotheses proposed.

The decline in US crime was repeated in many other Western countries, some earlier and others later, and experts began to speak of a crime drop on an international scale (Tseloni et al., 2010). The internationalization of the phenomenon forced researchers to rethink some of the explanations put forward, which did not hold up outside the context of North America, and to come up with more universal hypotheses (Tonry, 2014).

The debate that emerged in Europe was especially interesting because the crime drop was even called into question. Thus, although a decline in property crime and lethal violence was indeed confirmed, the same cannot be said about all other violent crime, which appears to continue to rise (Aebi and Linde, 2010). The need to take account of how crime figures are computed (Tonry, 2014) and to standardize crime measurement in Europe has been raised (Aebi and Linde, 2010). However, the problem seems to extend beyond official data and specific validity and reliability issues since the use of other alternative sources has also led to discrepancies. Thus, whereas some argue that, with alternative sources of information, the decline in violent crime does not hold up (Killias and Lanfranconi, 2012), others suggest the opposite (Estrada, 2006).

In any case, there is no consensus regarding the drop in the international crime rate, or at least not with the same characteristics in all countries or at the same time (Killias and Lanfranconi, 2012). Nor can one speak of a drop in total crime because the most recent analyses have found that crime has not declined uniformly among all population groups (Butts and Evans, 2014; Estrada et al., 2016; Kim et al., 2015, Nilsson et al., 2017).

In short, there is still much to learn about the crime drop and its possible causes. Criminology is facing a major challenge and it is up to criminologists to reflect on this because we may be overlooking important lessons for criminal policy and practice (Tseloni et al., 2010).

The aim of this work is to determine whether juvenile crime is decreasing in Spain. We then test the explanatory capacity of some of the hypotheses applicable to the Spanish context. Aggregate data from the police and self-reported data are used.

This analysis pursues three objectives. First, because it has been argued that young people are largely responsible for the crime drop (Butts and Evans, 2014; Kim et al., 2015), an analysis limited to trends in juvenile delinquency rates is relevant. Second, the availability of the third round of the International Self-Report Delinquency Study (ISRD3) allows us to analyse self-reported juvenile delinquency trends as an alternative source to official data and reduces criminal data validity problems in trend analysis (Elonheimo, 2014). Third, it makes sense to conduct a case study in an alternative country, different from those on which current crime trend studies have focused (Howard et al., 2000) since a crime drop is not necessarily an inevitable universal phenomenon (Killias and Lanfranconi, 2012). 
Moreover, the Spanish case allows us to analyse the influence that social and political change may have on juvenile crime trends. Spanish society has been transformed in recent decades in the aftermath of a swift democratization process. In addition, two opposing movements have taken place in social policy within a short span of time: first, the consolidation of child and family policy up until the first decade of the 21 st century laying the foundations of a welfare state; and then the economic crisis starting in 2009 and the ensuing budget cuts having a major negative impact on this welfare state.

\section{Previous research: Why the crime drop?}

As noted above, lower crime figures may be attributed to many different factors. Here we will limit our analysis to three hypotheses that shed light on the juvenile crime rate in Spain.

\section{Demographic shifts}

The decline in crime has been attributed to the ageing population. In other words, to the extent that the youth population is responsible for a large proportion of crime, an ageing population should cause crime rates to fall. However, there was little conclusive evidence showing that demographic change accounted for the change in the overall rate of violence (Farrell et al., 2014). According to Levitt, 'demographic shifts may account for a little more than one-sixth of the observed decline in property crime in the 1990s, but it is not an important factor in the drop in violent crime' (2004: 172).

Furthermore, other demographic changes such as increased immigration and the tail end of the baby boom have offset the impact of the ageing population and led to a temporary increase in the number of teenagers and young adults (Levitt, 2004).

The idea that immigration leads to higher crime rates has played an important role both in criminological theory and in debates on immigration policy (Wadsworth, 2010). However, in recent years, North American data have shown that the decline in crime has coincided with an increase in immigration and diversity, to the point that the latter could be considered responsible for the decline (Sampson and Bean, 2006).

Indeed, there is solid evidence from North American research to suggest that immigration provides a protective effect, because it is associated with strong community ties generating cultural commitment to compliance and guarding against the criminogenic effects of social disorganization, strain, and economic and social marginalization (Wadsworth, 2010). The paradigmatic example of this is the Latin paradox in the USA, that is, Hispanic Americans do better on a wide range of social indicators, including propensity to violence (Martinez, 2002). The cities with the largest increases in immigration between 1990 and 2000 experienced the largest decreases in homicide and robbery during the same period (Martinez and Stowell, 2012). Although the overall impact of immigration on the crime drop is modest, it is not trivial (Stowell et al., 2009).

However, the situation appears to be different in Europe, where research has shown that, in many countries, immigrant crime rates are higher than the average crime rates among the general population (Killias, 2011). Regarding juvenile offenders (ISRD-2 data), Junger-Tas (2012) shows that the prevalence of violent behaviour was higher among immigrant groups 
compared with the national population, but the differences in property offences were small. Nevertheless, there are important differences between countries. In the Netherlands, Germany, Denmark, Finland, Russia and the USA, there are no significant differences. However, in Switzerland, Sweden, Slovenia, Italy and the Czech Republic, immigrant youths commit more crimes than non-immigrants (Salmi et al., 2015).

Arguably, owing to the inconsistent nature of the data, the effect of immigration on the crime drop in Europe has not been evaluated. No analysis has been conducted on how differences across European countries in the ethno-cultural characteristics of immigrants might affect these inconclusive data. More evidence is needed, because there are many methodological issues to consider (samples, data collection methods, definitions of immigration, etc.) (Salmi et al., 2015).

In the past two decades, Spain has become a recipient country for immigrants, with a subsequent change in the demographic characteristics of its population. Although adult delinquency has been associated with immigration, owing to the overrepresentation of immigrants in the justice system, there is no evidence for a higher participation of immigrants in criminal behaviour (García-España, 2001). Unfortunately, there are no studies on crime rates in the young immigrant population, but, in other areas, findings show that immigrant juveniles consume fewer drugs than their Spanish counterparts (Marsiglia et al., 2008); participate in school violence at similar rates (Llorent et al., 2016); and enjoy a high quality of life (Nunes et al., 2016).

Consequently, our first hypothesis (H1) is that immigrant juveniles' engagement in crime is similar to that of Spanish juveniles and the corresponding crime trends are also similar.

\section{Stronger economies}

Criminology has long assumed that there is a positive correlation between economic deprivation and inequality and crime rates. Therefore, economic expansion in the 1990s was believed to account for the falling crime rates (Rosenfeld and Messner, 2009).

However, the fact that the decline in crime has continued beyond 2008 and coincided with a massive economic recession corroborates the weak link between macroeconomics and crime (Levitt, 2004). Furthermore, although great advances have been made in understanding the relationship between social disadvantage and crime, the continuation of a sizeable crime drop, despite the financial crisis, has not been fully explained by criminological research (Newburn, 2016).

Nilsson et al. (2017) also found it interesting that crime is decreasing at the same time as income inequality is increasing, thus showing that the crime drop is not homogeneous. They note that falling crime is more prevalent among the highest earners whereas increased crime is more focused on lower income levels. Thus, the crime drop has not been uniform and the socio-economically disadvantaged groups are also suffering the highest conviction and victimization rates (Hunter and Tseloni, 2016).

The economic crisis in Spain has taken an especially high toll on the most socially disadvantaged sectors, particularly affecting households with children (Flores et al., 2014). Based on the literature, our second hypothesis is that the juvenile crime trends in Spain are not homogeneous and vary between disadvantaged and non-disadvantaged youths (H2). 


\section{Gender gap}

Crime trend analysis has generally been gender-neutral, which means, really, that the study has focused on crimes committed by men. Thus, the crime drop refers to violent and property crimes committed by males, and all the theories reviewed previously try to explain this fact.

Across the world, crime rates for women have been and still are very low compared with those for men. However, the distance between them, the 'gender gap', seems to have diminished in some countries, which would indicate that the gap could be narrowing. Two meta-theories have attempted to explain this gender gap trend: (a) the offender behavioural change thesis, and (b) policy change in response to certain antisocial behaviours.

According to the behavioural change thesis, women's participation in criminal activity has grown because of emancipation and equal opportunities. Despite strong social support for this hypothesis (Hine and Welford, 2012), trend analysis has been unable to confirm it. Although it is true that official data from the USA and England show an increase since the 1990s in non-lethal violent crimes perpetrated by women, no significant changes have been observed in other places studied, such as Canada or the Nordic countries (Estrada et al., 2016; Schwartz, 2013).

Hence, the policy change hypothesis has gained strength with respect to certain forms of violence. As noted earlier, a rise in female crime has been observed only in some countries and in some crimes - simple assault and aggravated assault according to official data. The definition of these crimes is somewhat ambiguous, which gives weight to the idea of net widening enforcement; also, it would explain why these increases have been detected at earlier stages of the criminal justice system (Schwartz, 2013). In other cases, the participation in this type of crimes has increased similarly for females and males (Hsieh and Schwartz, 2018). More importantly, the increase in non-lethal violence by girls has been confirmed only in official figures, and alternative self-reported or victimization data are not conclusive (Schwartz et al., 2009). The change seems to have been especially noticeable in relation to domestic and intimate partner violence (IPV). Domestic violence and IPV have now been labelled as violence per se, sparking changes in the way police deal with domestic incidents. This has led to an increase in arrests of young people for domestic violence and IPV (Hsieh and Schwartz, 2018), especially of women, thus narrowing the gender gap.

Our third hypothesis (H3) is that, following the findings of Western countries, except the USA and the United Kingdom, the gender gap is narrowing in Spain. More specifically, crime rates for boys are approaching those of girls.

\section{Methodology}

\section{Source of information}

Two complementary sources of information have been used in this work: official data and self-reported data.

The official data come from the Spanish Ministerio del Interior (Ministry for Home Affairs), that is, police data, from 2001 to 2016 (the most recently published data). This period guarantees data homogeneity in terms of counting methodology. Also, this period 
covers only the years during which the Juvenile Criminal Act was in force, thus eliminating the bias that different laws could cause in the fluctuations observed. In order to make sure that sources are comparable, data from the National Police, Civil Guard and the Basque Autonomous Police will be used because these are the three sources of information that the Ministry of Home Affairs has been providing since 1998.

The self-reported data are taken from Spain's participation in the International SelfReport Delinquency Study (ISRD) at three different points in time (three rounds), 1992 (ISRD-1), 2006 (ISRD-2) and 2015 (ISRD-3). The three rounds were conducted across three different ages: ISRD-1 uses a sample taken from the general population, whereas ISRD-2 and 3 use samples from different school enrolment groups, for which, in both cases, the schools were randomly selected. Due to these differences between rounds, it has been advised that they should not be subjected to direct comparison (Enzmann, et al., 2017). To protect the comparison from bias due to those differences, we selected only subjects enrolled in school, between the ages of 14 and 18. The non-response rate was 30.0 percent in ISRD-1, a rate considered normal in this type of study (Rechea et al., 1995). In ISRD-2 and ISRD-3, the non-response rate was very low, 2.0 percent and 9.6 percent respectively. However, 2.1 percent of respondents in ISRD-2 and 0.7 percent in ISRD-3 did not answer antisocial questions and therefore 71 subjects were removed. Samples were as follows: ISRD-1: 1135 subjects (51.2 percent boys, 48.9 percent girls), average age 15.92 (standard deviation: 1.41); ISRD-2: 3020 subjects (48.4 percent boys and 51.6 percent girls), average age 15.97 (standard deviation: 1.37); ISRD-3: 2191 subjects (49.9 percent boys and 50.1 percent girls), average age 15.35 (standard deviation: 1.18). The data collection procedure varied across the three rounds, but no bias has been considered to exist that might prevent comparison (Savolainen et al., 2017).

\section{Variables}

Official crime rate. The official crime rate refers to detentions of juveniles (14-17 years old) for crimes and misdemeanours per 10,000 inhabitants between the ages of 14 and 17 (those under investigation or indicted are not counted).

Self-reported prevalence rates. The self-reported prevalence rate refers to the percentage of respondents who have engaged in each of the criminal behaviours once in their lives. Owing to changes in the questionnaire used for the different rounds, there are some criminal and antisocial behaviours that are not comparable. The following behaviours are compared: vandalism, shoplifting, burglary, vehicle theft (divided into bicycle theft, motorbike theft and car theft), car break-ins, robbery, carrying weapons, personal theft, group fighting and assault.

Self-reported total prevalence rate. The self-reported total prevalence rate refers to the percentage of respondents who have engaged in any of the criminal behaviours once in their lives.

Economic status of the families. The economically disadvantaged youths were differentiated from their non-disadvantaged counterparts using the self-reported data. Changes in 
the drafting of the different versions of the ISRD preclude the use of a complex index of family economic background. The only recourse is to use unemployment as a proxy in order to identify juveniles with fewer resources. A family is deemed to be without resources when both parents are unemployed. Although scholars dispute the use of unemployment as a measure, there is evidence that unemployment figures have a strong and significant impact on crime rates, and this effect has proved to be even stronger than the effect of income levels (Hooghe et al., 2010). Moreover, assuming that unemployment and poverty are different concepts, evidence shows that, in Spain, unemployment significantly raises the risk of poverty (Moreno et al., 2014).

Foreigners. For the analysis of the official data, a foreigner is considered to be any youth without Spanish nationality. With regard to self-reported data, those surveyed whose parents were both born in another country were considered foreign. Based on this criterion, foreign juveniles account for 16.4 percent in ISRD-1, 6.9 percent in ISRD-2 and 13.9 percent in ISRD-3. In ISRD-1, foreign juveniles are overrepresented because of the design of a subsample of vulnerable juveniles. There are no differences between natives and foreigners in terms of sex or age in any of the rounds. However, a higher number of foreign juveniles are in a situation of economic disadvantage in the three rounds. This is the case for 17.3 percent of foreigners compared with 6.7 percent of Spanish nationals $\left(\chi^{2}=93.158, p=.000\right)$.

Gender gap rate. Following Schwartz (2013), we use the female percentage (female rate / (female rate + male rate) $\mathrm{x} 100$ ) as a measure of the gender gap. In official data, this percentage reflects the proportion adjusted of girls in the detainee population. The selfreported data reflect the adjusted proportion of girls who have engaged in the behaviours studied. An increase in this percentage indicates that the gender gap is closing.

\section{Trends in Spanish juvenile delinquency}

\section{Official data}

First, we would note that Spain does not have a major juvenile delinquency problem. As indicated in the 2014 edition of the European Sourcebook of Crime and Criminal Justice Statistics, young people account for a very small percentage of the total number of detainees in the country, that is, 5.5 percent, which is well below the European average of 9.3 percent (Aebi et al., 2014) or 13.0 percent for violent crimes and 21.0 percent for property crimes in the USA (Butts and Evans, 2014).

Moreover, statistics show a clear downward trend in juvenile delinquency. Juvenile crime rates have been steadily decreasing over the 15-year period 2001-16. The juvenile detention rate (age 14 to 17) fell by nearly 50 percent between 2001 and 2016, from 124.84 to 68.62 per 10,000 inhabitants. Figure 1 puts this trend into context by differentiating between the two major categories of crime: property crime and violent crime. The graph shows how the decrease in juvenile delinquency is mostly due to a reduction in property crime, while violent crime statistics have remained stable over time - although the figures were lower for the last four years. 


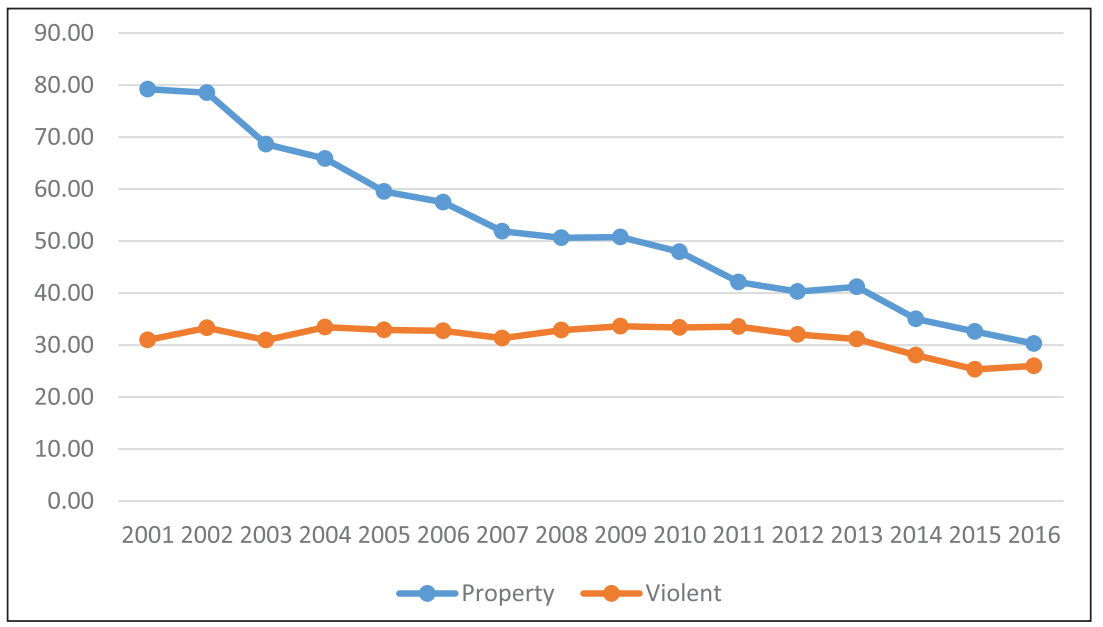

Figure I. Arrest rate of 14-17 year olds for violent and property crimes, 200I-16. Source: Ministry for Home Affairs and National Statistics Institute.

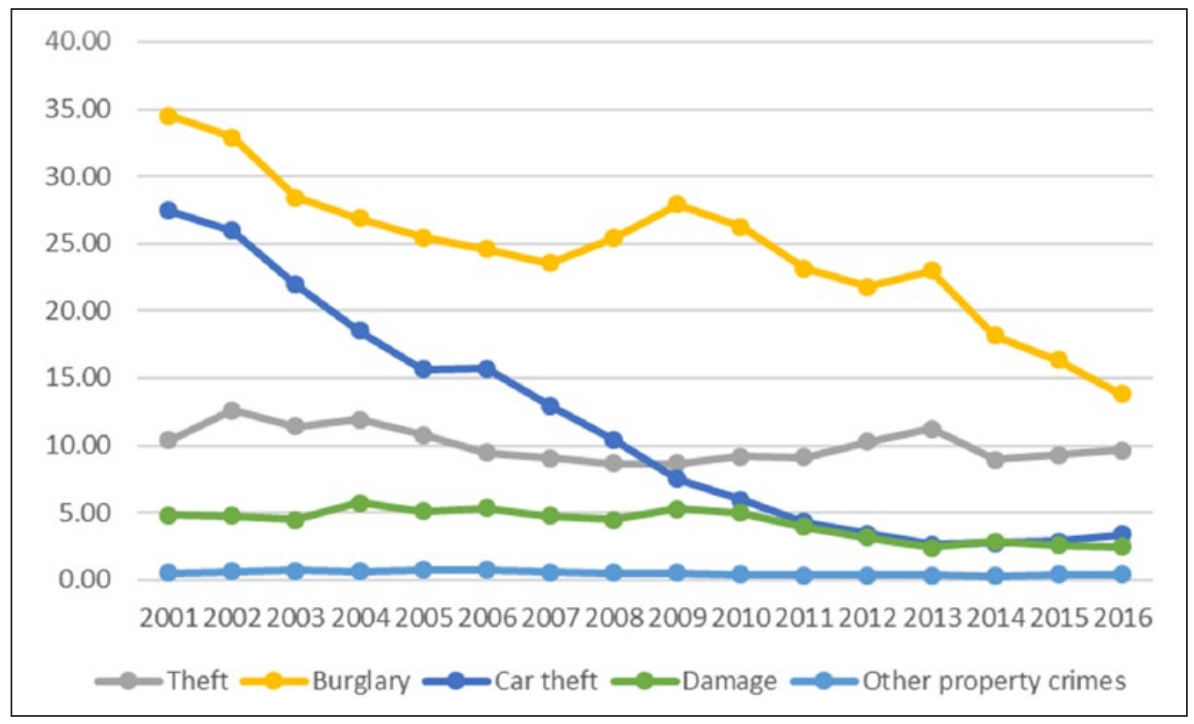

Figure 2. Arrest rate of I4-17 year olds for property crimes, 200I-I6.

Source: Ministry for Home Affairs and National Statistics Institute.

Figure 2 shows that all property crime has decreased over the period 2001-16, especially during the last five years. There was a particularly important reduction in car theft, whereas general theft figures were stable despite annual variations.

Figure 3 shows trends in violent crime. Robbery, although a property crime, is included in the category of violent crime because it is violent by definition. As the graph indicates, 


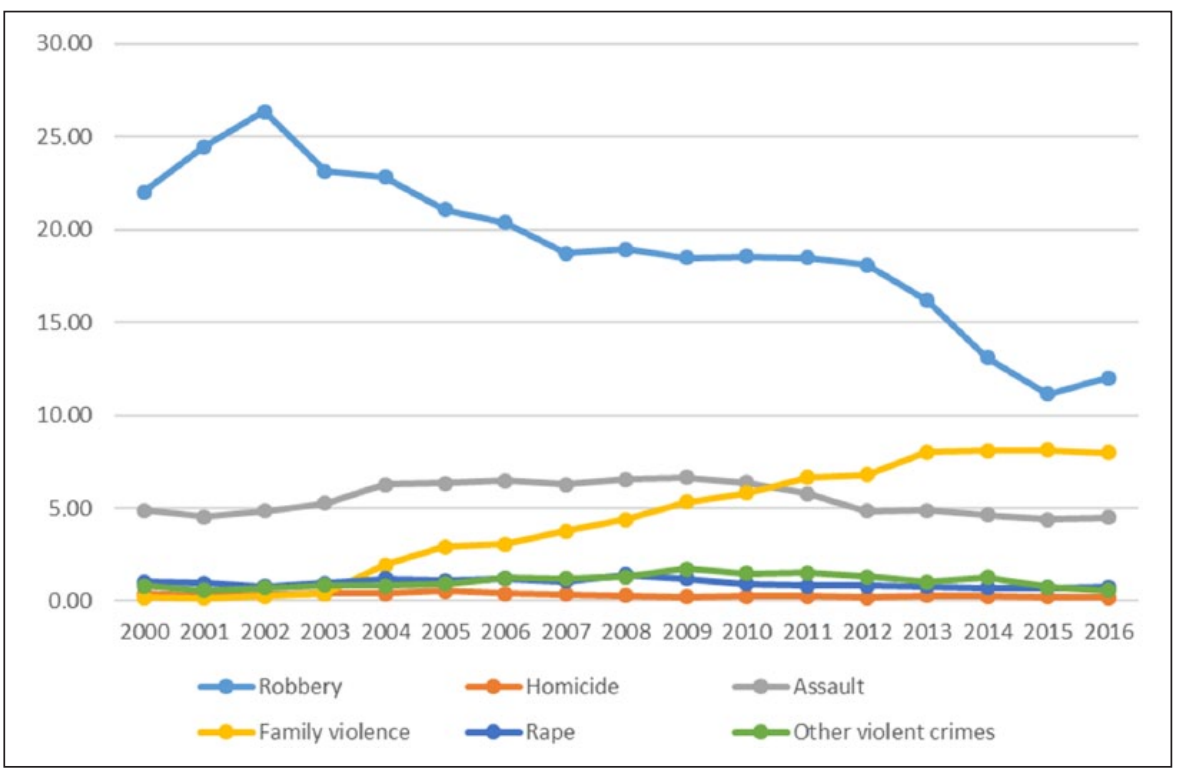

Figure 3. Arrest rate of I4-I7 year olds for violent crimes, 200I-I6.

Source: Ministry for Home Affairs and National Statistics Institute.

this behaviour has undeniably decreased. Homicide remains constant, whereas sex crimes and assault, after a small rebound between 2003 and 2008, have clearly been declining over the last five years. Lastly, domestic violence, encompassing both violence in intimate relationships between teenagers and child-parent violence, has risen steadily.

\section{Self-reported juvenile delinquency}

The data from the three ISRD study rounds allow us to compare the trends observed in the official data. As Table 1 shows, all the self-reported criminal behaviours show statistically significant trends, confirming how juvenile delinquency has changed in Spain over the last 20 years.

All criminal behaviour, except shoplifting and illegal downloads, decreased in the 2006 and 2013 national self-report studies (ISRD-2 and ISRD-3). Many behaviours, such as vandalism, burglary, group fighting and assault, have all decreased steadily from the time of the first self-report study in 1992 (ISRD-1) until now. However, shoplifting has increased over the last 20 years and vehicle theft, car break-ins and robbery have also increased, despite declining over the last 10 years. Lastly, illegal downloading, which obviously did not exist in 1992, has been on the rise.

In conclusion, the above results on juvenile crime in Spain are consistent with international figures. The two data sources agree on the notable decrease in burglary, a traditional indicator of property crime, as well as other typically juvenile behaviours, such as vandalism and group fighting. Over the last decade, there has been a consolidated decline in robbery and vehicle theft. 
Table I. Self-reported prevalence among juveniles of antisocial and criminal behaviour: |ISRD-I, ISRD-2, ISRD-3.

\begin{tabular}{lcccc}
\hline & ISRD-I (I992) & ISRD-2 (2004) & ISRD-3 (2015) & $\chi^{2}(2 \mathrm{gl})$ \\
\hline Vandalism & $54.0 \%$ & $15.7 \%$ & $7.2 \%$ & $1090.043^{* *}$ \\
Shoplifting & $21.9 \%$ & $26.5 \%$ & $27.3 \%$ & $\left.12.46\right|^{* *}$ \\
Burglary & $24.2 \%$ & $3.5 \%$ & $2.8 \%$ & $631.807^{* *}$ \\
Vehicle theft & $2.1 \%$ & $5.2 \%$ & $3.1 \%$ & $26.158^{* *}$ \\
Car break-ins & $0.8 \%$ & $4.5 \%$ & $3.8 \%$ & $33.033^{* *}$ \\
Robbery & $0.8 \%$ & $2.0 \%$ & $1.4 \%$ & $\left.8.94\right|^{*}$ \\
Group fighting & $30.0 \%$ & $26.2 \%$ & $14.7 \%$ & $135.4^{* *}$ \\
Assault & $3.7 \%$ & $1.7 \%$ & $1.8 \%$ & $16.209^{* *}$ \\
Illegal downloads & - & $65.7 \%$ & $79.0 \%$ & - \\
\hline
\end{tabular}

$* \chi^{2}$ significant at $p \leqslant .05 ; * * \chi^{2}$ significant at $p \leqslant .01$

There are no studies on trends in self-reported antisocial behaviour that allow these results to be corroborated. However, Serrano, Godás, Rodríguez and Mirón (1996) found similar prevalence rates to those reflected in ISRD-1 for vandalism, robbery and assault. The data from the Health Behaviour in School-aged Children (HBSC) study show even lower prevalence rates than the data from ISRD-2 in 2002 and 2006 in vandalism and group fighting, two of the behaviours that showed the largest decline. The HBSC also found a stable trend in violent behaviour from 2006 to 2014 (HBSC, 2002, 2006, 2010 and 2014).

However, some discrepancies have been observed between official and selfreported data in the case of assault. Whereas self-reported data show an initial decline and stable figures over the last decade, official data reveal an increase between 2004 and 2010, followed by a decline in the last five years. Trends cannot be detected with only two self-report rounds. These findings coincide with general European trends, in that they do not show a conclusive trend in violent crime, especially non-lethal violence (Aebi and Linde, 2010). The increase in dating violence and child to parent violence in Spain could be the result of heightened sensitivity to violence in Western countries leading to a rise in reporting offences (Kivivuori, 2014). This is especially true of domestic violence, as Spanish research has shown in adults (Benítez, 2004).

\section{Why the drop in juvenile crime in Spain?}

Next, we will discuss how the sociodemographic hypotheses formulated to explain the decrease in juvenile delinquency apply to Spain.

\section{Demographic changes}

In Spain, the population was steadily ageing during the 1990s and then levelled off at the beginning of the 21 st century. Spanish citizens under the age of 18 have made up 17.8 percent of the population on average between 2001 and the present. ${ }^{1}$ This demographic 


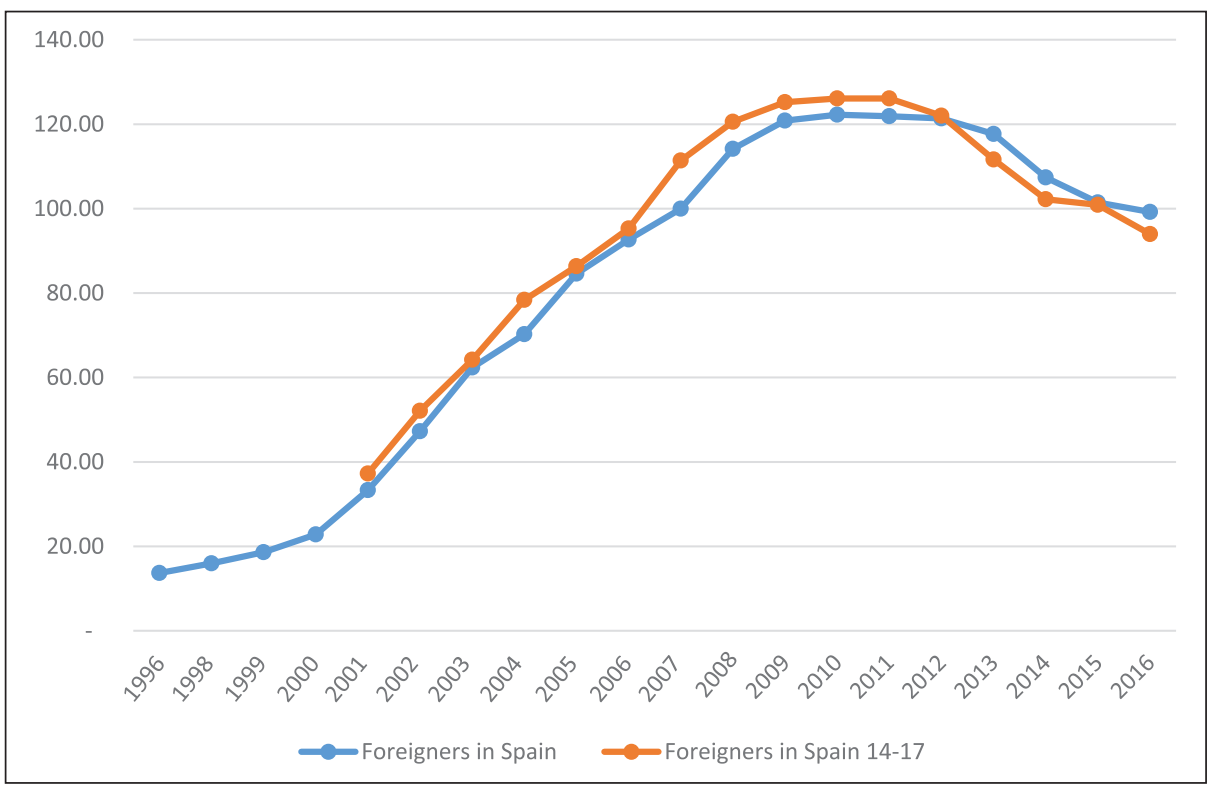

Figure 4. Foreign population per 1000 inhabitants in Spain, 1996-2016.

Source: National Statistics Institute.

stabilization was largely due to the effect of immigration, and the question now is whether this accounts for the decrease in the absolute number of juvenile detentions.

Figure 4 shows that Spain became a net receiver of immigrants starting in the year 2000, the immigration curve progressively rising until the beginning of the economic crisis, when a slight decrease in the foreign population can be observed. A large number of the immigrants during that period were young people.

Young foreigners living in Spain began their migratory journey with their parents, who came to Spain to work, and are therefore first-generation immigrants (UNICEF, 2009). The number of unaccompanied minors is very low, accounting for only 0.4 percent of all foreign minors in the country.

Figure 5 shows that, although the foreign population rose, the crime rates for foreigners detained declined significantly until 2011, remaining stable since then. Immigrant detainees are mostly from the countries accounting for the highest number, that is, Morocco (28.5 percent) and Romania (23.9 percent), followed by Ecuador ( 7.5 percent) and Colombia (7.3 percent).

Self-reported crime data show a great similarity between Spanish nationals and immigrants (Table 2). In the behaviours presenting significant differences, Spanish youths engaged more in these behaviours according to ISRD-1 (vandalism, burglary, and group fighting) and ISRD-2 (shoplifting). These differences disappeared in ISRD-3, associated with a notable decline in the participation of native juveniles.

Comparing the three ISRDs, for both groups the prevalence of the most habitual behaviours has decreased while that of less prevalent behaviours has remained stable. Only car break-ins follow a different trend, slightly on the rise among foreigners. 


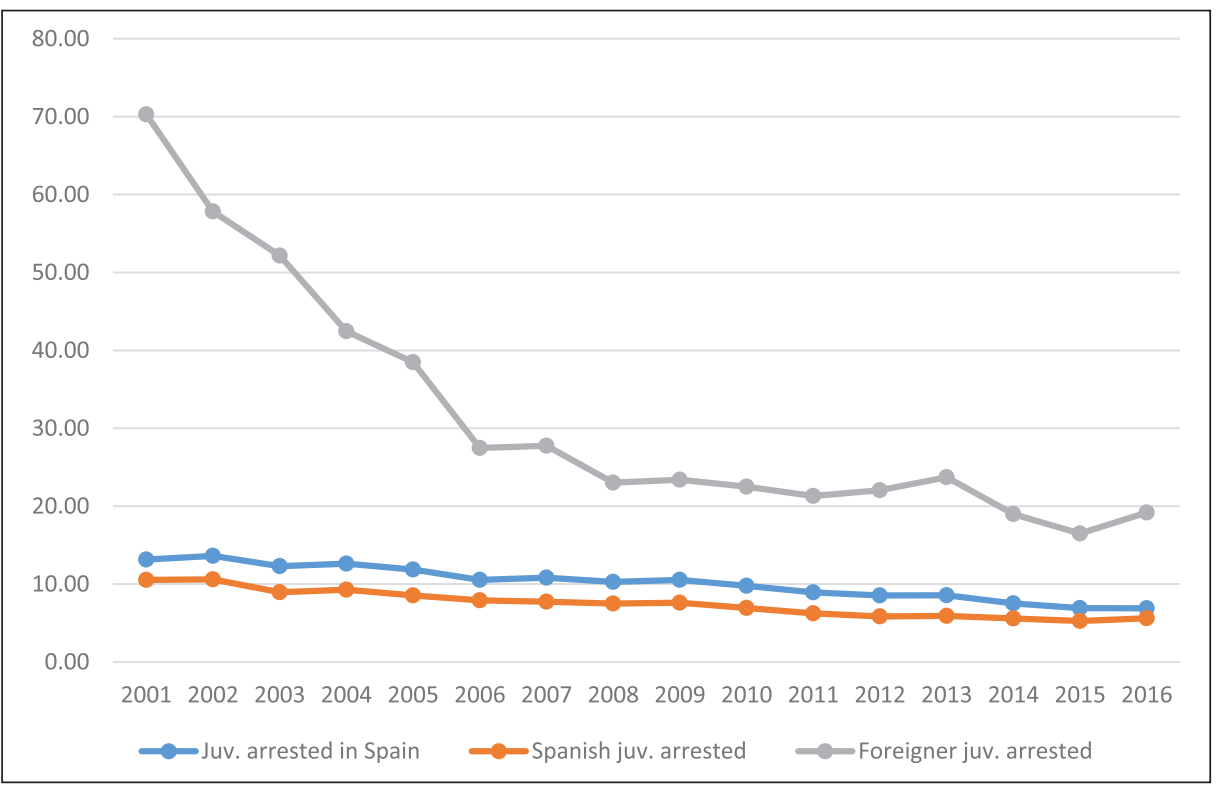

Figure 5. Arrest rate of I4-17 year olds by nationality, 200I-16.

Source: Ministry for Home Affairs and National Statistics Institute.

The percentage of young Spanish nationals engaging in any of the behaviours under study (see Figure 6) decreased significantly throughout the three rounds, although the decrease has been less pronounced since 2004. In contrast, a significant decrease was recorded among immigrants in 2004, but there is no change between ISRD-2 and ISRD3. In other words, as in the official data, participation in antisocial behaviours seems to have stabilized among immigrant juveniles.

The self-reported data support our hypothesis (H1) that the number of immigrants engaging in antisocial behaviour is similar to that of their Spanish counterparts. However, they are overrepresented in the official data. This finding is common in Europe: equal or even underrepresentation of immigrants involved in self-reported crime, whereas official immigrant crime rates are higher than crime rates in the general population (Hällsten et al., 2013). This cannot easily be explained. Econometric studies have suggested that the overrepresentation of immigrants is due to there being more men than women in this population (Alonso-Borrego et al., 2009). However, this is not so in the case of young immigrants in the years under study, according to the census data.

Hällsten et al. (2013) found that the gap between immigrant and Swedish juveniles in the official crime figures is largely explained by the difference in resources between their families and neighbourhoods. The official Spanish data do not allow this hypothesis to be tested, but the self-reported data show that, even though foreigner juveniles are more disadvantaged than Spanish juveniles, they commit fewer crimes. Nonetheless, lack of resources could be less a risk for initiating engagement in antisocial behaviour than for continuing this behaviour, which is especially reflected in the official data. 


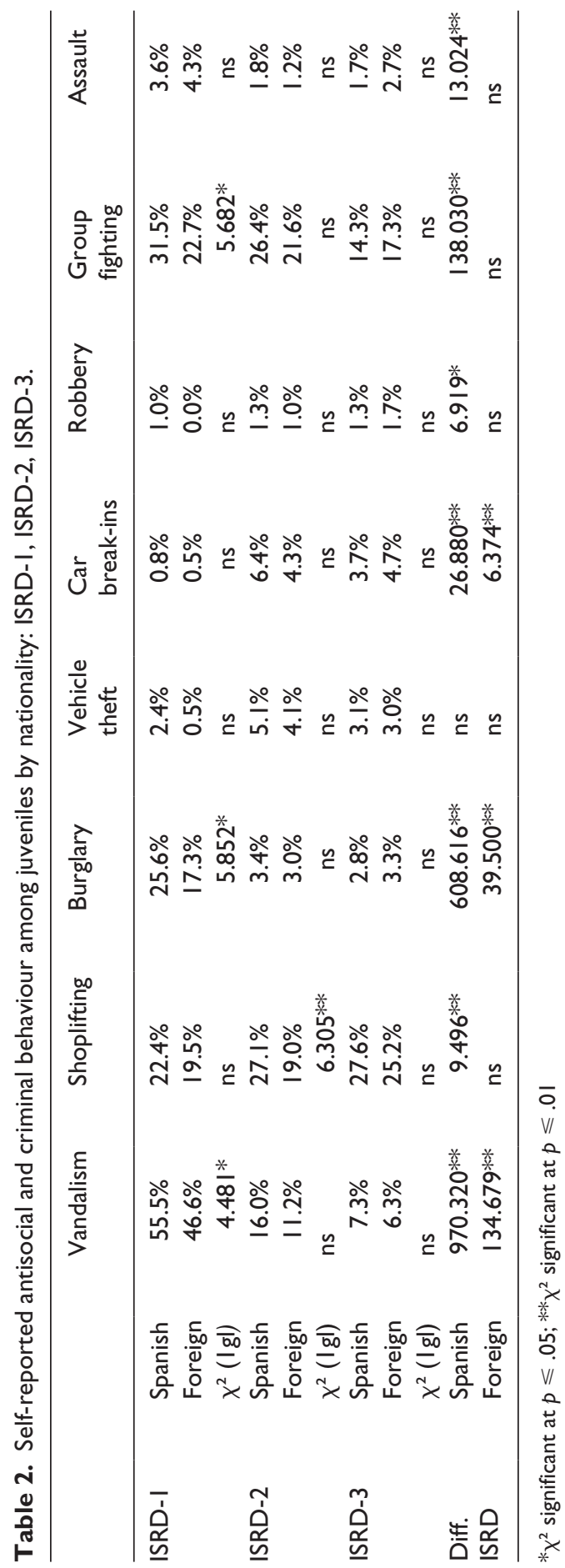




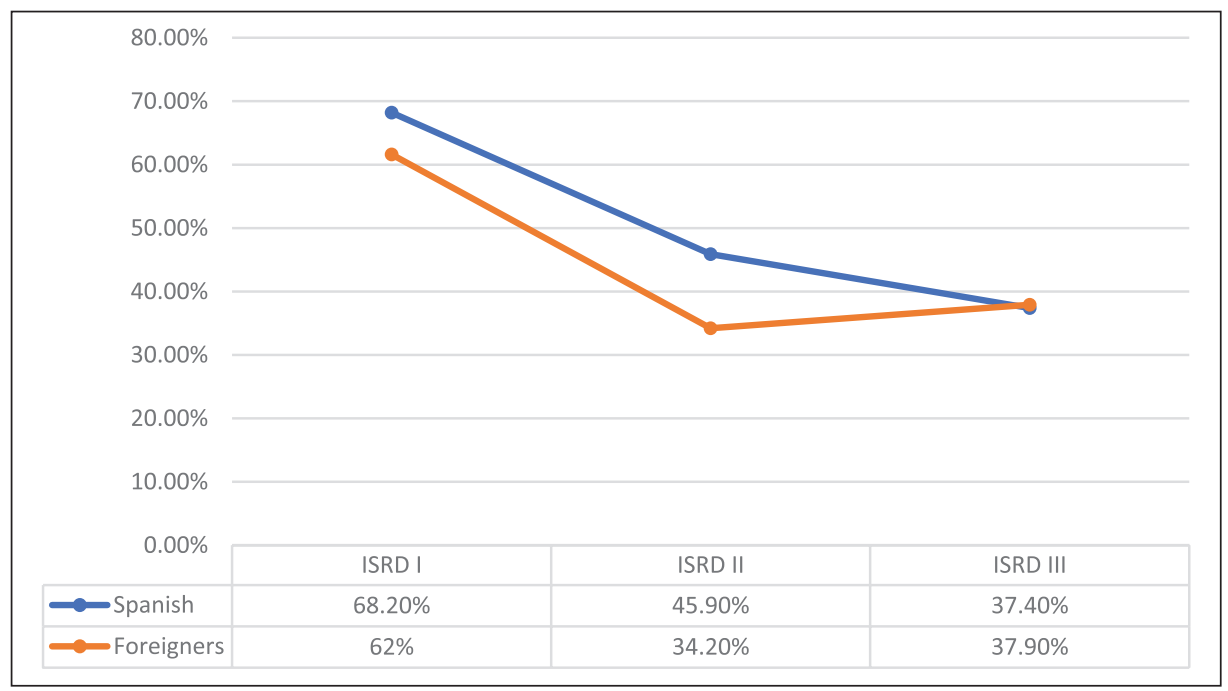

Figure 6. Self-reported total prevalence rate among juveniles by nationality: ISRD-I, ISRD-2, ISRD-3.

A possible social desirability bias has been detected in the self-reported measure depending on the ethno-cultural group of origin (Enzmann et al., 2017), which might partly explain their lower prevalence in the self-reported data. However, this bias explains neither the considerable decline in the rate of juveniles detained nor the similarity between the trends detected in the official and self-reported data, which is, ultimately, the aim of this study.

In short, both the official and the self-reported data show that, following a period of sharp decline in both groups, the rates among immigrants have stabilized, while rates among Spanish juveniles continue to fall.

\section{Stronger economies}

The drop in Spain's juvenile crime rate is paradoxical because the steepest decline was during the worst period of recent history characterized by a deeply entrenched economic recession causing a severe social crisis. Consequently, with the aggregate data we are not able to establish any association between the serious economic crisis in Spain and juvenile crime figures, as proposed by Levitt (2004). However, we can analyse self-reported data following the hypothesis of Nilsson et al. (2017) about the effect deprivation has on juvenile crime rates.

Table 3 shows that the crime trend is different for juveniles whose families are better off economically compared with those whose parents have fewer resources. Thus, crime trends in the first group show a statistically significant decline in vandalism, burglary, group fighting and assault, and a slight increase in property crimes, such as shoplifting, car theft, car break-ins and robbery. Conversely, findings for the most vulnerable group 


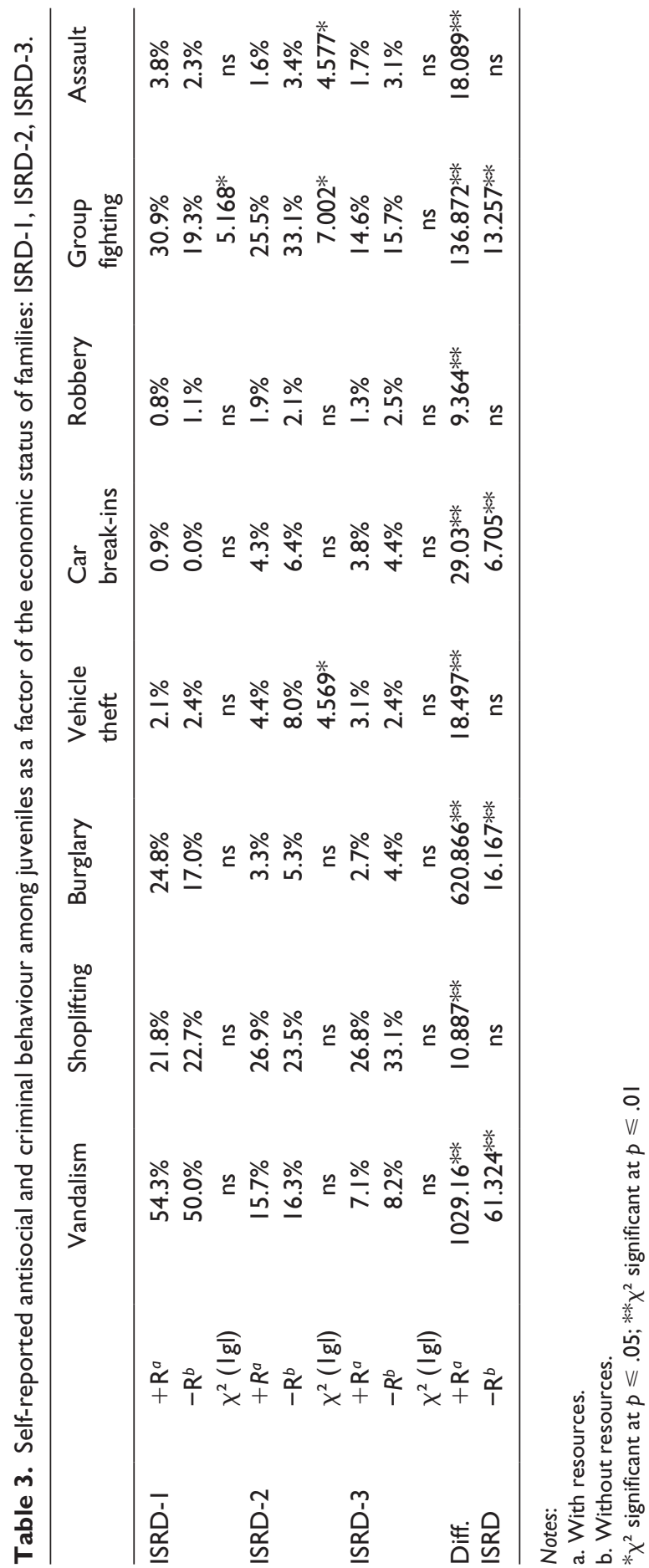




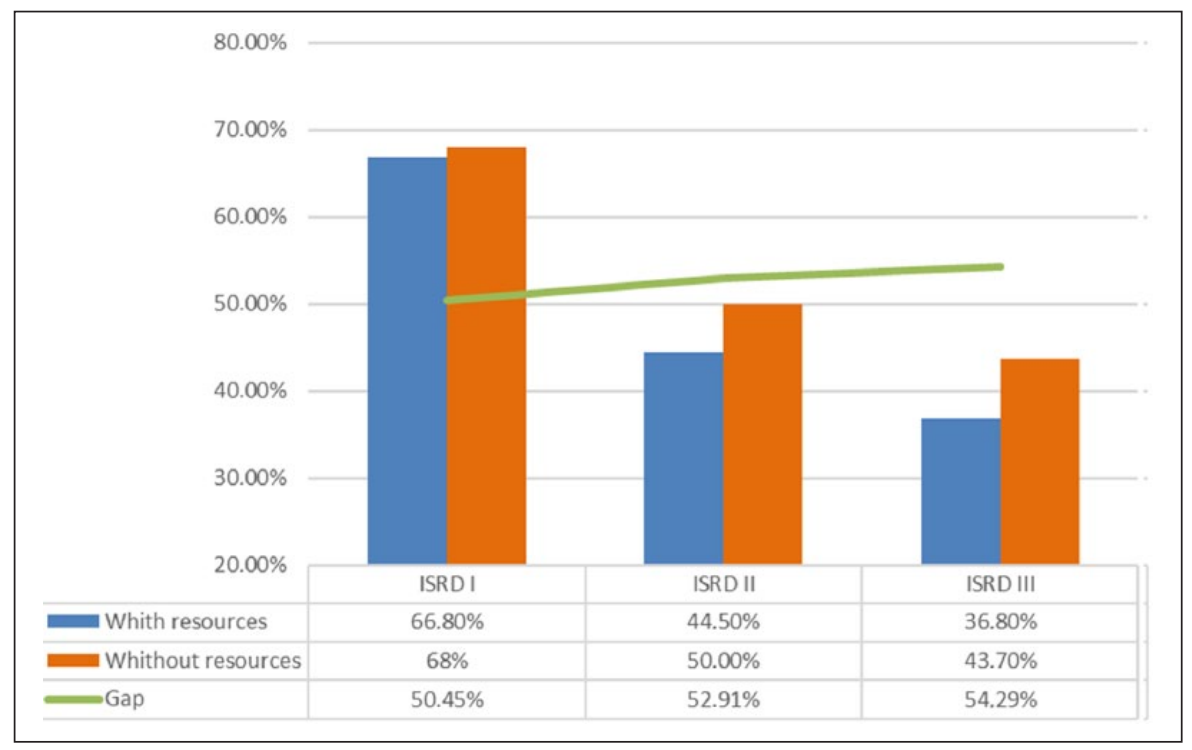

Figure 7. Self-reported total prevalence rate among juveniles by family resources: ISRD-I, ISRD-2, ISRD-3.

Note: Gap = proportion adjusted of juveniles without resources among juveniles who engaged in antisocial and criminal behaviours.

indicate a different trend. A statistically significant drop was observed only in vandalism since the decrease in group fighting was not significant. Other crimes increased in 2015 and the upward trend is statistically significant for shoplifting, burglary and car break-ins but not for the other crimes, which declined in 2004 but increased in 2015.

Data reveal that crime figures among youth from more economically disadvantaged families have followed a more negative trend than those for youth from families with greater economic resources (see Figure 7). Moreover, the improvements noted from 2004 in the more disadvantaged group came to an end in 2015, when Spain was immersed in one of the most difficult periods of the recession and the effects of the economic cutbacks were felt.

Consequently, hypothesis $\mathrm{H} 2$ is confirmed. Although aggregate trends might suggest there is no correlation between economic growth and crime rates (Fernández-Molina et al., 2017), individual data suggest otherwise and show, as Xenakis and Cheliotis (2013) found in the case of Greece, that the criminogenic impact of the financial crisis is neither linear nor uniform.

These data should arguably be seen in the context of the social policy of countries in Southern Europe and the impact this might have on crime trends. Spain launched its welfare state in the 1980s, later than the rest of Europe. During the 1990s, Spanish regions consolidated their policies and resources. Many of these policies included coverage for the most vulnerable groups. The model was perfected in 2000 when active employment policies and family support programmes were also implemented (Moreno 
et al., 2014). Since Spain does not have a serious problem with crime, it has not developed specific prevention policies but has rather focused on improving the living conditions of all citizens. ${ }^{2}$

In addition to these policies, the welfare state model prevalent in South European countries, which depends on the family to ensure well-being and welfare, has also had its own effect on crime prevention. The important intra-familial transfers (tangible and intangible) characterizing Mediterranean Europe (Moreno, 2001) weave an important network of social support and strengthen informal control that structurally prevents and stops crime (Cid and Martí, 2016). It could be said that the social and family model of these South European countries is a good antidote to delinquency, especially juvenile delinquency, and this is borne out by the low figures for South European countries in comparison with others in Europe (Aebi et al., 2014).

The family welfare model (Ferrera, 2010), together with the consolidation of social policies targeting the general population, could therefore be considered a good crime prevention strategy (Knepper, 2012). However, the serious cuts since 2010 directly affecting support programmes for families (Moreno et al., 2014), children and youth (Planas et al., 2014) have had devastating effects on the most disadvantaged groups. The fact that the crime rate of young people from families with fewer resources is rising in the context of a clear decline confirms hypothesis $\mathrm{H} 2$ and suggests that families have not been able to sufficiently support these children and that social protection of the most vulnerable is necessary to ensure their proper development.

\section{Trends by gender}

Figure 8 shows arrest rates and Figure 9 shows the gender gap for each crime category.

Official data show that, in Spain, the arrest rate for juveniles is fairly stable or decreases for both boys and girls, and the gender gap is narrowing. However, this trend is not due to an increase in the girls' rate but rather because the drop in the boys' rates is slightly higher than that of girls.

Self-reported data (Table 4) show that crime trends are similar for boys and girls, although there are some differences that are worth highlighting. The decrease in vandalism, burglary and group fighting is statistically significant for both groups; however, the increase in car theft and car break-ins and robbery occurs only among boys. The opposite occurs with shoplifting, which increases significantly only in the case of girls. There is no clear trend for assault, falling in 2004 but rising again in 2015.

Figure 10 shows the gender gap involved in vandalism and violent behaviour. The proportion of girls has decreased significantly in vandalism, a behaviour that declined drastically among the adolescents surveyed, but even more so among girls. In contrast, the proportion of girls engaging in fighting or assault has grown, which means that the number of girls did not decline as much as that of boys. In assault, boys show a downward trend throughout the period whereas girls show a fluctuating pattern, with a slight decrease compared with the first round.

In short, the official and self-report data on juvenile delinquency in Spain show a stable or slightly downward trend that is similar for boys and girls (see Figure 11). The gender gap has diminished and the proportion of women out of total arrests for 


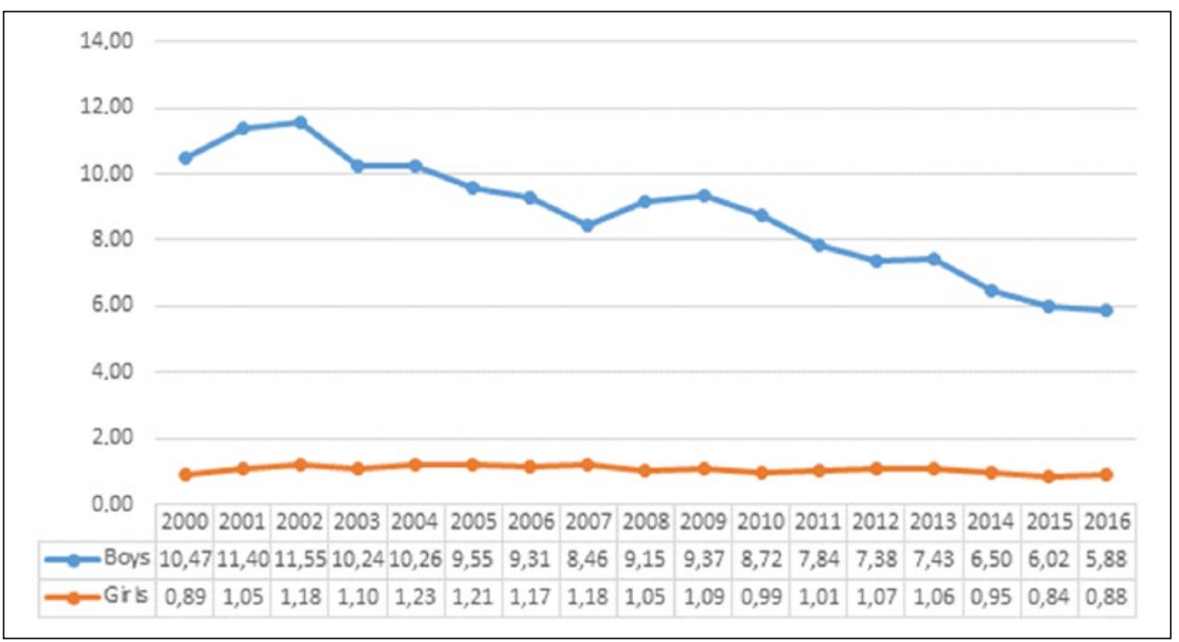

Figure 8. Arrest rate of 14-17 year olds by sex, 2000-16.

Source: Ministry for Home Affairs.

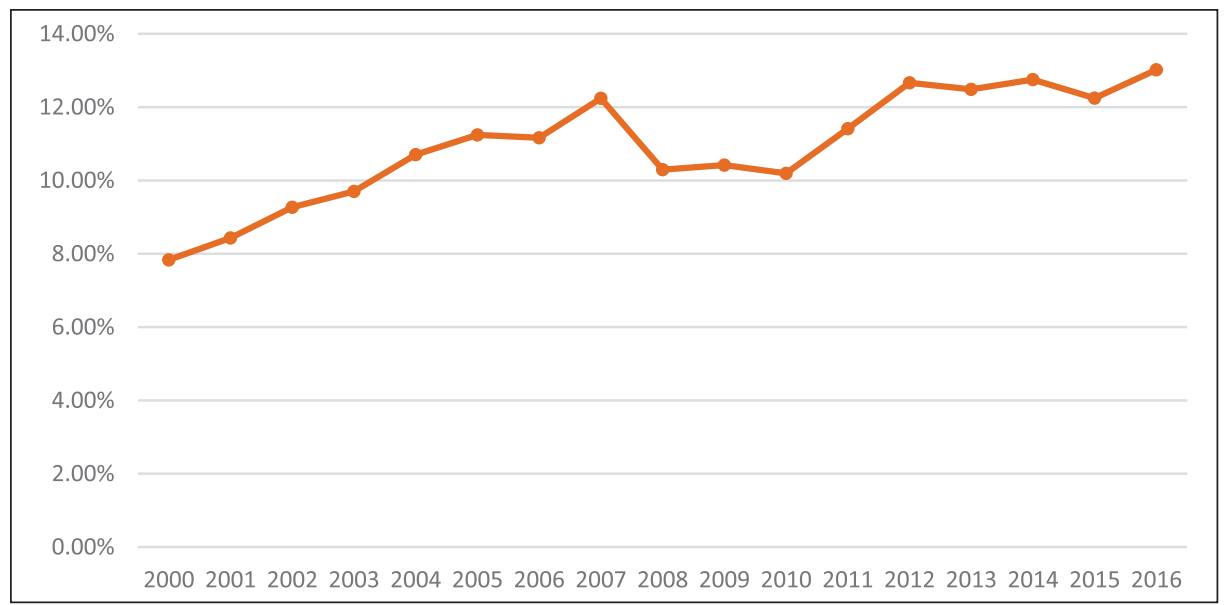

Figure 9. Gender gap in arrestees' population (14-17 year olds), 2000-16.

Source: Ministry for Home Affairs.

self-reported behaviours has grown slightly. However, this is due to a steeper decline in the number of boys and not to an increase in the number of girls engaging in violence or other crimes, which confirms our hypothesis (H3).

As far as we know, there are no studies on gender gap trends in Spain or in other South European countries. However, these results are in line with those found in other European countries and in recently democratized countries (Hsieh and Schwartz, 2018).

Spain has improved significantly in terms of gender equality, but this has not led to a negative behavioural change in girls; in contrast, juvenile delinquency levels remain 


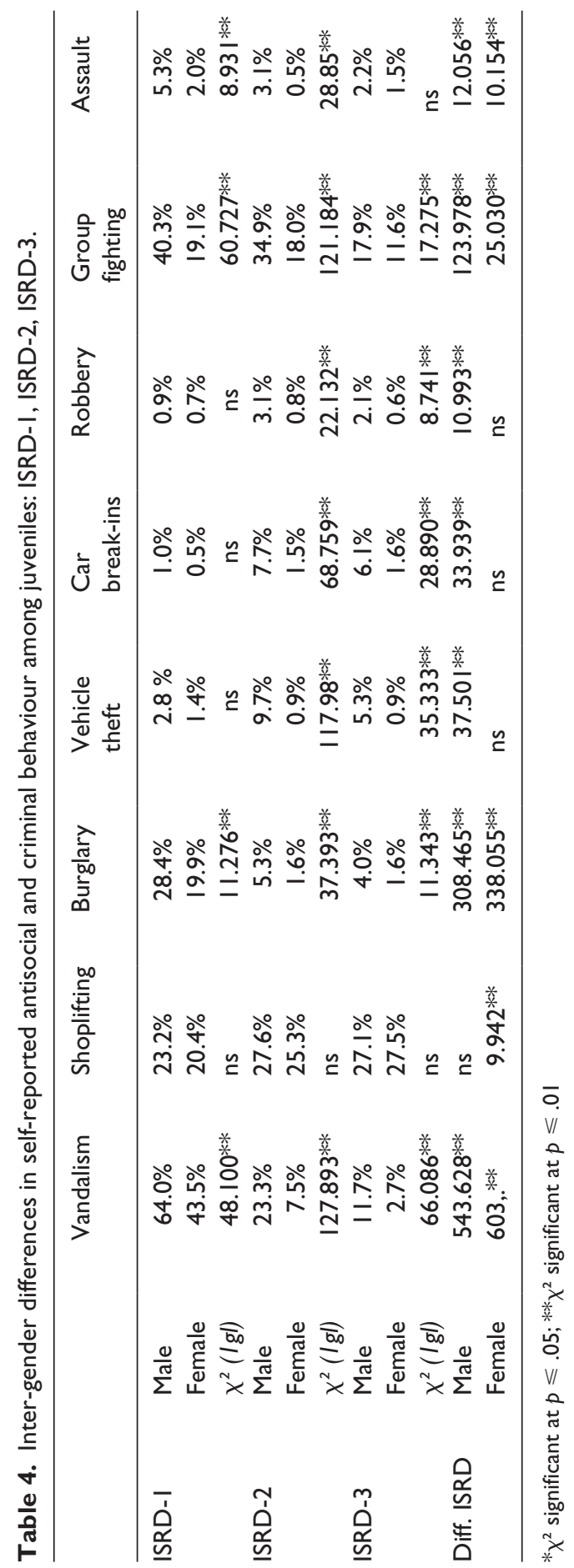




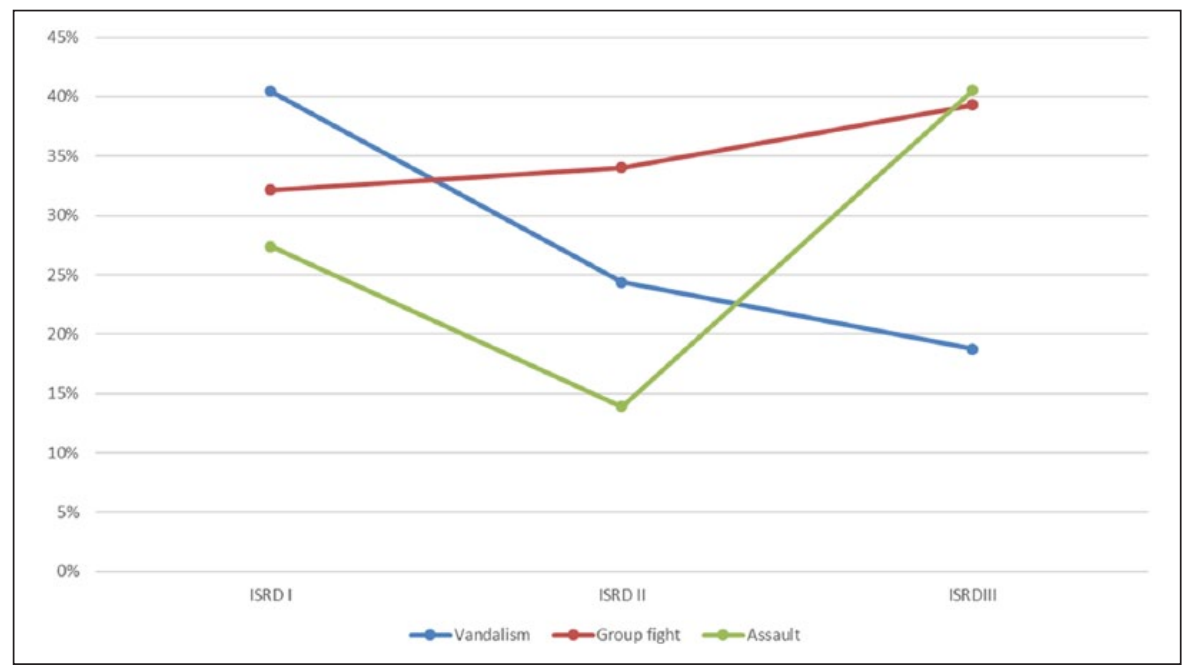

Figure 10. Gender gap in self-reported prevalence of vandalism, group fighting and assault among juveniles: ISRD-I, ISRD-2, ISRD-3.

ISRD-Spain I, II and III.

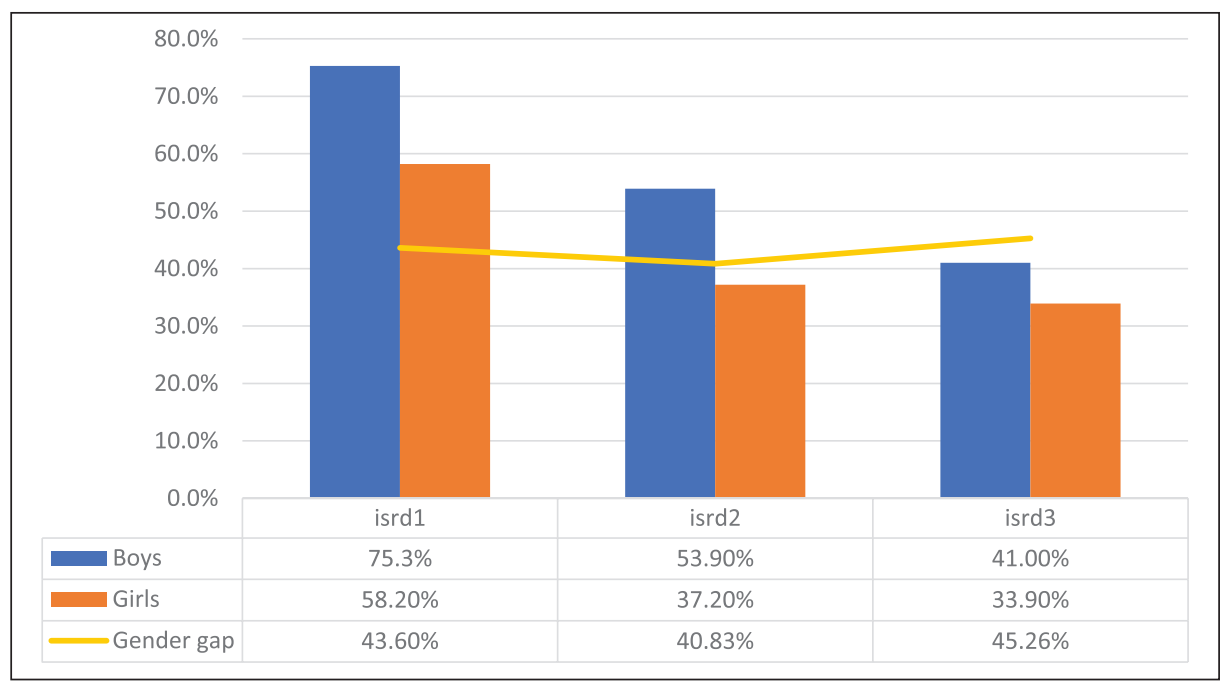

Figure I I. Self-reported total prevalence rate among juveniles by sex and gender gap: ISRD-I, ISRD-2, ISRD-3.

relatively low and have even decreased among females. Thus, in Spain the emancipation hypothesis should be reconsidered and, as Estrada et al. (2016: 17) point out, 'gender equality may have potential as a means of explaining why men's crime levels are moving towards those of women, rather than the reverse'. It can even account for why crime is 
rising among the most disadvantaged groups, which seem have the lowest levels of equality (Lei et al., 2014).

Estrada et al. (2016, 2017) suggest that gender equality may be spreading values and behaviour traditionally considered feminine (and not criminogenic) among males. Taking a slightly different tack, we consider that the impact of equality on the gender gap can be explained from the perspective of masculinities (Messerschmidt and Tomsen, 2012). That is, equality has changed the way youths live and express their gender. Boys are moving away from the type of masculinity traditionally associated with high-risk behaviours, juvenile mortality and antisocial behaviour, among other issues (Evans et al., 2011). In the same vein, the data on youth health show a significant decline in the gender gap in death rates by suicide, traffic accidents and external causes in Spain from 2000 to 2016. This is a consequence of a substantial decrease in the prevalence of these types of deaths among boys but not among girls (Injuve, 2017).

Both hypotheses suggest stimulating lines of future research on the gender gap, but can also be taken into account in the debate on the overall crime drop. However, it would be necessary to establish valid criteria and indicators to assess gender equality. Hence, we believe that studies need to be expanded to cover different countries and societies because important paradoxes surrounding the issues of gender equality and violence (Gracia and Merlo, 2016) must be taken into account. For example, according to the EU gender equality index, Spain is at the European average in terms of equality and is ranked 29th in the 2016 global gender gap report. However, it has one of the lowest rates in Europe and the world in terms of gender violence, school violence and other forms of violence. In contrast, the Nordic countries, with the highest equality ranking, have violence rates (both in official statistics and in victimization surveys) higher than Spain, for example (FRA, 2014; HBSC, 2002-2014; UNODC, 2013). Furthermore, the findings of studies attempting to determine the effect of patriarchy on antisocial behaviour are inconsistent, both those comparing indicators of family functioning (Robitaille, 2017) and those comparing countries (Thijs et al., 2015). For example, Savolainen et al. (2017) found that structural measures of patriarchy capture environmental conditions that increase opportunities for delinquency in women and girls in their study. However, normative measures influence amelioration of offending in men but not in women.

\section{Conclusions}

Although crime on a global scale is clearly declining, this phenomenon has not manifested itself in the same way or at the same time in all countries. Therefore, countries need to take stock of their crime rate trends, not only to gain insight into the health of their systems (Tonry, 2014), but also to contribute to cumulative knowledge about the decline of crime and the possible lessons that can be taken from such an understanding (Tseloni et al., 2010). That is the aim of this work, which analyses the Spanish case.

The Spanish juvenile crime trends described are very similar to those of other European countries. Property crime and the most serious violent crimes have declined, while domestic violence and theft seem to have increased. The increase in certain violent crimes appears to be the result of cultural changes in Western societies, which are 
apparently more sensitive towards violence, contributing to a net widening effect capturing less serious types of violent crime.

However, what is perhaps an important but unexpected finding is that the overall crime drop in the youth population conceals certain particularities. The drop is detected especially among non-economically disadvantaged Spanish boys. In contrast, the socially disadvantaged, girls and, in recent years, immigrant juveniles do not feature in this decreasing trend.

These results could contribute to a global debate about crime drop. Public policies appear to have had an influence on crime trends. The social welfare model, ensuring aid to families and juveniles until the most recent economic crisis, could account for the overall reduction in crime. However, we have detected an increase in crime rates among the most disadvantaged young people, that is, those who have suffered the most from cuts in social policies. This should alert us to the fact that the most vulnerable have not been able to access or benefit from the opportunities, aid or learning that have favoured the overall decline in crime.

Some of these findings may be linked to gender equality. Traditionally, it was believed that the increase in female delinquency was the price to be paid for emancipation, but fortunately this belief is untrue. Instead, it is the boys who are approaching the girls' crime rates. In Spain, as in other countries, gender equality may be having an effect on the deviant behaviour of young people, girls and boys alike, which needs to be explored in greater depth.

Finally, it is worth noting certain limitations of this study. Regarding the official data, we have used those that are closest to the phenomenon and that are considered most reliable: police arrests. Unfortunately, these data are not sufficiently separated according to socioeconomic level.

About the self-reported data, we homogenized the samples by age, selecting only school-registered respondents. Furthermore, only the behaviours collected in the same way across the three instruments were compared. In this sense, we believe the data are comparable, but they are not exempt from bias derived from different data collection procedures. Moreover, the self-reported data may present a social desirability bias and thus not be a faithful reflection of the criminal behaviour of the respondents (Enzmann et al., 2017). This study takes prevalence measured with the ISRD as an approximation of the crime rate and compares it with official crime rates as a way top to obtain a more precise image of events, but we do not assume that the data provide a precise picture of juvenile crime. Finally, although the data cover a 23 -year period and were collected at three points in time, more measurements would have helped to ensure higher-quality trend analyses.

\section{Acknowledgements}

Esther Fernández-Molina is very grateful for the warm welcome received at Stockholm University and would especially like to thank Professors Felipe Estrada and Anders Nilsson for their support. The authors would also like to thank José Cid for his suggestions. Lastly, we would like to thank the Spanish Ministry for Home Affairs, especially Francisco Sánchez, for his patience in providing and explaining the official data. We are grateful to the anonymous reviewers who provided constructive and helpful comments on an earlier version of the manuscript. 


\section{Funding}

This research was conducted with funding from the regional government of Castille-La Mancha, Spain (PPOII-2014-009-P). An initial draft was written during visiting research funded by the University of Castilla-La Mancha at Stockholm University Department of Criminology.

\section{Notes}

1. According to National Statistics Institute figures, the proportion of children aged 0-17 years in the total population fell from 24.50 percent in 1991 to 17.94 percent in 2001. Since 2001, that segment of the population continued to fall very gradually until 2007 when it recovered slightly, the average of the last 15 years being 7.80 percent.

2. According to the 2014 European Sourcebook of Crime and Criminal Justice Statistics (Aebi et al., 2014), the crime rate in Spain has consistently been much lower than the European average.

\section{ORCID iDs}

Raquel Bartolomé Gutiérrez (iD https://orcid.org/0000-0003-2013-9053

Esther Fernández Molina iD https://orcid.org/0000-0002-3103-0232

\section{References}

Aebi M et al. (2014) European Sourcebook of Crime and Criminal Justice Statistics, 5th edn. Publication Series No. 80. Helsinki: European Institute for Crime Prevention and Control, affiliated with the United Nations (HEUNI).

Aebi M and Linde A (2010) Is there a crime drop in Western Europe? European Journal on Criminal Policy and Research 16(4): 251-277.

Alonso-Borrego C, Garoupa N, Perera M and Vázquez P (2009) Inmigración y delincuencia en España, 1999-2007: explicando un comportamiento excepcional. In: Boldrin M (ed.) Efectos económicos de la Inmigración en España. Madrid: Marcial Pons, 61-98.

Benítez M (2004) Violencia contra la mujer en el ámbito familiar: cambios sociales y legislativos. Madrid: Edisofer.

Blumstein A and Wallman J (2006) The Crime Drop in America. Cambridge: Cambridge University Press.

Butts J and Evans D (2014) The second American crime drop. Juvenile Justice Sourcebook 61.

Cid J and Martí J (2016) Structural context and pathways of desistance. Research in Spain. In: Shapland J, Farrall S and Bottoms A (eds) Global Perspectives on Desistance. London: Routledge, 66-82.

Elonheimo H (2014) Evidence for the crime drop: Survey findings from two Finnish cities between 1992 and 2013. Journal of Scandinavian Studies in Criminology and Crime Prevention 15(2): 209-217.

Enzmann D, Kivivuori J, Marshall I, Steketee M, Hough M and Killias M (2017) A Global Perspective on Young People as Offenders and Victims. The Netherlands: Springer.

Estrada F (2006) Trends in violence in Scandinavia according to different indicators: An exemplification of the value of Swedish hospital data. British Journal of Criminology 46(3): 486-504.

Estrada F, Bäckman O and Nilsson A (2016) The darker side of equality? The declining gender gap in crime: Historical trends and an enhanced analysis of staggered birth cohorts. British Journal of Criminology 56(6): 1272-1290.

Estrada F, Nilsson A and Bäckman O (2017) The gender gap in crime is decreasing, but who's growing equal to whom? Sociologisk forskning 54(4): 359-363. 
Evans J, Frank B, Oliffe J and Gregory D (2011) Health, illness, men and masculinities (HIMM): A theoretical framework for understanding men and their health. Journal of Men's Health $8(1): 7-15$.

Farrell G, Tilley N and Tseloni A (2014) Why the crime drop? Crime and Justice 43(1): 421-490.

Fernández-Molina E, Bernuz M and Bartolomé R (2017) Spain. In: Decker S and Marteache $\mathrm{N}$ (eds) International Handbook of Juvenile Justice. Switzerland, Springer International Publishing AG, 421-444.

Ferrera M (2010) The South European countries. In: Castel FG, Leibfried S, Lewis J. and Pierson C (eds) The Oxford Handbook of the Welfare State. Oxford: Oxford University Press, 616-629.

Flores M, García-Gómez P and Zunzunegui MV (2014) Crisis económica, pobreza e infancia. ¿Qué podemos esperar en el corto y largo plazo para los 'niños y niñas de la crisis'? Informe SESPAS 2014. Gaceta Sanitaria 28: 132-136.

FRA (European Union Agency for Fundamental Rights) (2014) Violence against women: An EU-wide survey. URL (accessed 19 July 2018): http://fra.europa.eu/en/publication/2014/ violence-against-women-eu-wide-survey-main-results-report.

García-España E (2001) Delincuencia de extranjeros, un análisis criminológico. Valencia: Tirant la Blanch.

Gracia E and Merlo J (2016) Intimate partner violence against women and the Nordic paradox. Social Science and Medicine 157: 27-30.

Hällsten M, Szulkin R and Sarnecki J (2013) Crime as a price of inequality? British Journal of Criminology 53: 456-481.

HBSC (Health Behaviour in School-aged Children) España (2002, 2006, 2010 and 2014) Informes. URL (accessed 19 July 2018): https://www.hbsc.es/informes.

Hine J and Welford J (2012) Girls' violence: Criminality or resilience? In: Ungar M (ed.) The Social Ecology of Resilience. New York: Springer, 157-169.

Hsieh M and Schwartz J (2018) Female violence and gender gap trends in Taiwan: Offenderbehavioral changes or net-widening enforcement explanations? Feminist Criminology 13(1): $28-58$.

Hooghe M, Vanhoutte B, Hardyns W and Bircan T (2010) Unemployment, inequality, poverty and crime: Spatial distribution patterns of criminal acts in Belgium, 2001-06. British Journal of Criminology 51: 1-20.

Howard G, Newman G and Pridemore W (2000) Theory, method, and data in comparative criminology. Criminal Justice 4(4): 139-211.

Hunter J and Tseloni A (2016) Equity, justice and the crime drop: The case of burglary in England and Wales. Crime Science 5(1): 1.

Injuve (2017) Informe Juventud en España 2016. URL (accessed 23 July 2018): http://www.injuve. es/observatorio/demografia-e-informacion-general/informe-juventud-en-espana-2016.

Junger-Tas J (2012) Delinquent behaviour in 30 countries. In: Junger-Tas J, Haen Marshall I, Enzmann D, Killias M, Steketee M and Gruszczynska B, The Many Faces of Youth Crime: Contrasting Theoretical Perspectives on Juvenile Delinquency across Countries and Cultures. New York: Springer.

Killias M (2011) Immigration and Crime: The European Experience. EU-US Immigration Systems. No. 19. Florence: EUI.

Killias M and Lanfranconi B (2012) The crime drop discourse - or the illusion of uniform continental trends: Switzerland as a contrasting case. In: Van Dijk J, Tseloni A and Farrell G (eds) The International Crime Drop. London: Palgrave Macmillan, 268-278.

Kim J, Bushway S and Tsao H (2015) Identifying classes of explanations for crime drop: Period and cohort effects for New York State. Journal of Quantitative Criminology 1-19. 
Kivivuori J (2014) Understanding trends in personal violence: Does cultural sensitivity matter? Crime and Justice 43(1): 289-340.

Knepper P (2012) An international crime decline: Lessons for social welfare crime policy? Social Policy and Administration 46(4): 359-376.

Lei M, Simons R, Simons L and Edmond M (2014) Gender equality and violent behavior: How neighborhood gender equality influences the gender gap in violence. Violence and victims 29(1): 89.

Levitt S (2004) Understanding why crime fell in the 1990s: Four factors that explain the decline and six that do not. Journal of Economic Perspectives 18(1): 163-190.

Llorent VJ, Ortega-Ruíz R and Zych I (2016) Bullying and cyberbullying in minorities: Are they more vulnerable than the majority group? Frontiers in Psychology 7: 1507.

Marsiglia F, Kulis S, Luengo M, Nieri T and Villar P (2008) Immigrant advantage? Substance use among Latin American immigrant and native-born youth in Spain. Ethnicity and Health 13(2): 149-170.

Martinez R (2002) Latino Homicide: Immigration, Violence and Community. New York: Routledge.

Martinez R and Stowell J (2012) Extending immigration and crime studies: National implications and local settings. The Annals of the American Academy of Political and Social Science 641(1): 174-191.

Messerschmidt JW and Tomsen S (2012) Masculinities. In: DeKeseredy WS and Dragiewicz M (eds) Routledge Handbook of Critical Criminology. New York: Routledge.

Moreno L (2001) La 'vía media' española del modelo de bienestar mediterráneo. Papers: Revista de sociología 63/64: 67-82.

Moreno L, del Pino E, Marí-Klose P and Moreno-Fuentes F (2014) Los sistemas de bienestar europeos tras la crisis económica. Colección Estudios $n^{\circ} 3$. Serie Análisis. Área Políticas Sociales. Programa EUROsocial. Madrid.

Newburn T (2016) Social disadvantage, crime, and punishment. In: Dean H and Platt L (eds) Social Advantage and Disadvantage. Oxford: Oxford University Press, 322-345.

Nilsson A, Estrada F and Bäckman O (2017) The unequal crime drop: Changes over time in the distribution of crime among individuals from different socioeconomic backgrounds. European Journal of Criminology 14(5): 586-605.

Nunes C, Hernando Á, Lemos I, Ayala-Nunes L, Oliva C and Coronado C (2016) Quality of life of Portuguese and Spanish adolescents. A comparative study between natives and immigrants. Ciencia and saude coletiva 21(4): 1137-1144.

Planas A, Soler P and Feixa C (2014) Juventud, políticas públicas y crisis en España: ¿Triángulo mágico o triángulo de las Bermudas? Revista Latinoamericana de Ciencias Sociales, Niñez y Juventud 12(2): 551-564.

Rechea C, Barberet R, Montañés J and Arroyo L (1995) La Delincuencia Juvenil en España: Autoinforme de los Jóvenes. Madrid: Ministerio de Justicia e Interior.

Robitaille M (2017) Développement des comportements antisociaux de l'enfance au début de l'âge adulte: différences sexuelles et théories du contrôle. $\mathrm{PhD}$ thesis, Université de Montréal, Canada.

Rosenfeld R and Messner S (2009) The crime drop in comparative perspective: The impact of the economy and imprisonment on American and European burglary rates. British Journal of Sociology 60(3): 445-471.

Salmi V, Kivivuori J and Aaltonen M (2015) Correlates of immigrant youth crime in Finland. European Journal of Criminology 12(6): 681-699.

Sampson R and Bean L (2006) Cultural mechanisms and killing fields: A revised theory of community-level racial inequality. In: Peterson R, Krivo L and Hagan J (eds) The Many Colors of Crime: Inequalities of Race. New York: New York University Press, 8-36. 
Savolainen J, Applin S, Messner S, Hughes L, Lytle R and Kivivuori J (2017) Does the gender gap in delinquency vary by level of patriarchy? A cross-national comparative analysis. Criminology 55(4): 726-753.

Schwartz J (2013) A 'new' female offender or increasing social control of women's behavior? Cross-national evidence. Feminist Studies 39(3): 790-821.

Schwartz J, Steffensmeier DJ and Feldmeyer B (2009) Assessing trends in women's violence via data triangulation: Arrests, convictions, incarcerations, and victim reports. Social Problems 56(3): 494-525.

Serrano G, Godás A, Rodríguez D and Mirón L (1996) Perfil psicosocial de los adolescentes españoles. Psicothema 8(1).

Stowell J, Messner S, McGeever K and Raffalovich L (2009) Immigration and the recent violent crime drop in the United States: A pooled, cross-sectional time-series analysis of metropolitan areas. Criminology 47(3): 889-928.

Thijs P, Van Dijk I, Stoof R and Notten N (2015) Adolescent problem behaviour: The gender gap in European perspective. European Journal of Criminology 12(5): 598-615.

Tonry M (2014) Why crime rates are falling throughout the Western world. Crime and Justice 43(1): 1-63.

Tseloni A, Mailley J, Farrell G and Tilley N (2010) Exploring the international decline in crime rates. European Journal of Criminology 7(5): 375-394.

UNICEF (2009) Ni ilegales, ni invisibles. Realidad jurídica y social de los menores extranjeros en España. Barcelona: Unicef.

UNODC (United Nations Office on Drugs and Crime) (2013) Global Study on Homicide. URL (accessed 19 July 2018): https://www.unodc.org/gsh/.

Wadsworth T (2010) Is immigration responsible for the crime drop? An assessment of the influence of immigration on changes in violent crime between 1990 and 2000. Social Science Quarterly 91(2): 531-553.

Xenakis S and Cheliotis L (2013) Crime and economic downturn. The complexity of crime and crime politics in Greece since 2009. British Journal of Criminology 53(5): 719-745.

Zimring F (2006) The Great American Crime Decline. New York: Oxford University Press. 